\title{
A scenario greenhouse gas emissions reduction activity of Indonesia economy sectors
}

\begin{abstract}
Emission reduction potential in the sector, there are 34 sectors of the economy that have the potential to reduce emissions such as electricity, mining, agriculture, forestry, industry, transport and others. Baseline, through decomposition analysis with known emission rate of change of $9.5 \%$ per year and the amount of emissions by 2010,410 million tCO2e then emissions by 2020 if no intervention would be 799 million tons. Emission reduction scenarios by 2020, without intervention would be 799 million tons, with a reduction of $26 \%$ (208 million tCO2e) then becomes 591 million tCO2e emissions; and a reduction of $41 \%$ (328 million tCO2e), the emissions would be 471 million tCO2e. Because it is multidisciplinary, complex and dynamic should address the impact of climate change do cross-sectoral, involving various stakeholders for adaptation and mitigation of climate change. Planning, evaluation, control and verification of each sector and each GHG emissions should also be done regularly and continuously.
\end{abstract}

Keywords: scenario, emissions, baseline, reduction, Indonesia
Volume 3 Issue 3- 2018

\author{
Hairin Fajeri \\ Departement of Socio Economic, Faculty of Agriculture, \\ Lambung Mangkurat University, Indonesia
}

Correspondence: Hairin Fajeri, Departement of Socio Economic, Faculty of Agriculture, Lambung Mangkurat University, Komplek Barata No.55 Kalimantan Selatan, Banjarbaru Indonesia 707I4, Email hairinfajeri@yahoo.co.id

Received: May 30, 2018 | Published: June 13, 2018

\section{Introduction}

\section{Background}

Reports of the Intergovernmental Panel on Climate Change showed that the increase in average temperature from 1850-1899 to 2001-2005 has reached $0760 \mathrm{C}$. The global sea level rose at an average rate of $1.8 \mathrm{~mm}$ per year during the period 1961 to 2003. rise of sea levels recorded during the 20th century is estimated at about 0.17 $\mathrm{m} .{ }^{1}$ The IPCC report also stated that economic activity has contributed to global warming since the middle of the 20th century. Global warming will continue to increase at a faster rate in the $21^{\text {st }}$ century if nothing is done to address it. Global warming causes climate change and increase the frequency and intensity of extreme weather events. IPPC concluded that global warming could cause significant changes to the biological and physical systems, such as an increase in tropical cyclone intensity, changes in rainfall patterns, ocean salinity patterns, wind, animal and plant reproduction, species distributions and population, epidemics, and also affects a wide range of ecosystems at high latitudes (including the Arctic and Antarctic), the height of the location, as well as coastal ecosystems. Based disasters recorded in International Disaster Database, the ten largest Indonesian disaster events that occurred after 1990 and most of these disasters are related to weather, particularly floods, followed by drought, wildfires and increased disease endemic. It shows that weather-related disasters have increased in frequency and intensity. Economic losses from the ten largest disaster nearly 26 billion USD, approximately $70 \%$ which can be attributed to the climate.

The above shows that a systematic and integrated efforts by the global community to reduce the rate of global warming, combined with efforts to increase the capacity of overcoming towards climate change is needed. Fundamental changes in the planning system is therefore needed. Present and future climate must be one of the main factors in determining the basis of national development plans, regional and sectoral, for short, medium and long term. Addressing climate change in the context of sustainable development requires mitigation of climate change, and also the development of robust systems to the long-term impact of climate change. This effort requires a multi-sectoral approach at the national and regional levels. Adaptation efforts must be combined with mitigation, adaptation will not be effective if the rate exceeds the ability of adaptation to climate change. Mitigation is the effort to reduce greenhouse gas emissions from various sources / sectors and increase absorption by various factors, thereby reducing the burden of the impact of climate change on future generations.

As one of the stages of the process of emission reduction efforts to address climate change, this study answers some fundamental problems below.

I. How much the level of greenhouse gas emissions for a period of several years into the future, if no mitigation and adaptation?

II. How scenarios of emission reductions to be made to control and reduce these emissions?

\section{Purpose}

To estimate the amount of emissions over the next few years as a baseline, and make the emission reduction scenarios.

\section{Benefits}

a. Can be used to describe the national development plan ahead or development strategies that include low emissions and / or economic growth resilient to climate change.

b. Can be used in formulating a plan, action, monitor, control and verification emisi GRK to address climate change and as a guide by the various institutions in implementing a coordinated and integrated effort to address climate change. 


\section{Theoretical Basis}

This section serves as a reference for assessing, in the next chapter, the potential for future emissions pathways, for mitigation measures. For the systematic assessment of the main drivers of GHG emissions trends, and the remainder using decomposition analysis based Rich identity. To factors such as energy, population, gross domestic product (GDP) per capita, energy intensity, GHG emissions and energy intensity. For other sectors, the last two factors are combined into the intensity of greenhouse gas emissions. Second, consider the main driver is defined as the processes, mechanisms, and characteristics that affect the community through emission factors, such as fossil fuel reserves and availability, consumption patterns, structural and technological changes, and behavioral choices. The main drivers are subject to the policies and measures that can be applied to, and act on GHG emissions. Changes in the underlying driver, in turn, led to changes in the direct drivers and, ultimately, the trend of greenhouse gas emissions. The influence of direct drivers on greenhouse gas emissions can be measured through analysis of decomposition; the underlying securities directly driver in the driver, however, was not easy and, for that reason, it is difficult to measure in terms of the main effects on greenhouse gas emissions. In addition, sometimes the driver can directly influence the underlying drivers in the reverse direction. Policies and measures in turn affect this interaction. Figure 1 reflects the interconnection between greenhouse gas emissions, the driver directly, the underlying driver, policies and measures as well as interaction in the three groups through the dotted line.

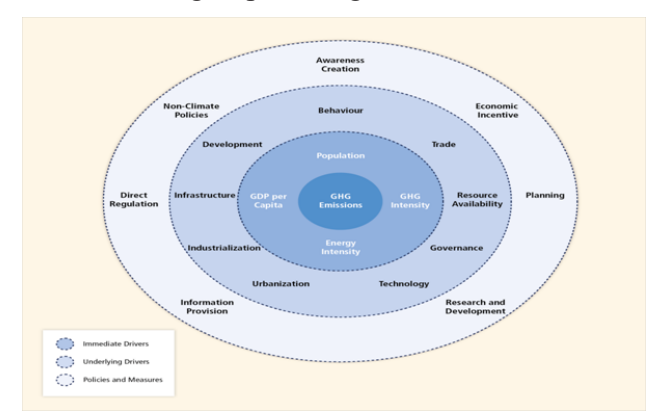

Figure I Interconnection between greenhouse gas emissions, direct drive, policies and actions. ${ }^{2}$

\section{Methods}

To achieve the goal of the research is carried out research activities include

\section{Data used}

1. Data in the form of economic sectors that emit greenhouse gas emissions:

2. Carbon Dioxide $\left(\mathrm{CO}_{2}\right)$

3. Metana $\left(\mathrm{CH}_{4}\right)$

4. Non-Methanic Volatile Organic Compounds (NMVOC)

5. Nitrogen-oxide (NOx)

6. Sulfur Dioxide $\left(\mathrm{SO}_{2}\right)$

7. Nitrous Oxide $\left(\mathrm{N}_{2} \mathrm{O}\right)$

8. Amonia $\left(\mathrm{NH}_{3}\right)$

9. Carbon Monoxide (CO)

\section{Socio-economic data}
1. GDP Using exchange rates
2. GDP Using purchasing power parities
3. Population

\section{Top of form}

\section{Data source}

I. IEA International Energy Agency (IEA) ${ }^{3} \cdot \mathrm{CO}_{2}$ Emissions from Fuel Combustion (2013 edition). Paris, France: OECD/IEA. ${ }^{3}$

II. Boden et al. ${ }^{4}$ Global, Regional, and National Fossil Fuel $\mathrm{CO}_{2}$ Emissions." Carbon Dioxide Information Analysis Center (CDIAC), Oak Ridge National Laboratory, U.S. Department of Energy, Oak Ridge, Tenn., U.S.A.

III. EIA ${ }^{5}$ U.S. Energy Information Administration (EIA). International Energy Statistics Washington, DC: U.S. Department of Energy.

IV. WIOD ${ }^{6}$ World Input Output Database (WIOD) (Table 1).

Table I Data sources

\begin{tabular}{lll}
\hline Database & Temporal coverage & Accuracy \\
\hline CDIAC & $* * * *$ & $* *$ \\
& $(175 I-2011)$ & \\
IEA & $* * *$ & $* * *$ \\
& $(1971-2011)$ & \\
EIA & $* *$ & $* *$ \\
WIOD & $(1980-2011)$ & \\
& I9* & $* * *$ \\
\hline
\end{tabular}

\section{Data processing}

Data processing descriptive statistics and by decomposition using Rich's identity.

Data processing descriptive statistics and by decomposition using Rich's identity such as the following: $\mathrm{Kaya}^{7}$ identity: the relative change in time.

$$
\mathrm{Cy} / \mathrm{Cx}=\mathrm{Py} / \mathrm{Px}(\mathrm{G} / \mathrm{P}) \mathrm{y} /(\mathrm{G} / \mathrm{P}) \mathrm{x}(\mathrm{C} / \mathrm{E}) \mathrm{y} /(\mathrm{C} / \mathrm{E}) \mathrm{x}
$$

Where $\mathrm{x}$ and $\mathrm{y}$ represent eg two different years.

In this study, decomposition Rich served as:

$\mathrm{CO}_{2}$ emissions and a key driver

$$
\mathrm{CO}_{2}=\mathrm{P}(\mathrm{GDP} / \mathrm{P})(\mathrm{TPEs} / \mathrm{GDP})\left(\mathrm{CO}_{2} / \mathrm{TPEs}\right)
$$

Where:

$$
\begin{aligned}
& \mathrm{C}=\mathrm{CO}_{2} \text { emissions; } \\
& \mathrm{P}=\text { Population }
\end{aligned}
$$

GDP / P = Gross Domestic Product (GDP) / population* TPEs / GDP $=$ Total primary energy consumption per GDP* $\mathrm{CO} 2$ emissions $/ \mathrm{TPEs}=\mathrm{CO} 2$ per unit of TPEs 
*GDP in 2005 USD, based on purchasing power parity (purchasing power parity).

Note: The base year for the index reference is $1990(=100)$

$\mathrm{Kaya}^{7}$ identity is used to discuss the main driving force (key driver) $\mathrm{CO}_{2}$ emissions. For example, it shows that, the increase in population and GDP per capita has encouraged the trend of $\mathrm{CO}_{2}$ emissions; more than offset the decline in energy intensity. In fact, the carbon intensity of the energy mix is almost unchanged, due to the continued dominance of fossil fuels-especially coal-in the energy mix, and the slow pace of low-carbon technologies.

Once known subsequent decomposition calculate emissions:

1. The rate of change in emissions with the formula: the amount of change ( $\%$ ) divided by the base period (Years) $=y \% /$ year

2. Baseline Emissions: $\mathrm{y} \%$ / year $\mathrm{x}$ length $\mathrm{x}$ base period emissions in the base year

3. The amount of emission reduction $=\% \mathrm{x}$ emission baseline reduction Assess the emission reduction scenarios.

\section{Selecting the amount of GHG emission reductions}

Selection of the amount of emission reductions in accordance with the government's commitment to research such as the G20 summit in Pittsburg, Indonesia has committed to establish the necessary policies and measures, including the necessary instruments related that will reduce national emissions between $26 \%$ (without international assistance) and $41 \%$ ( with international assistance) by 2020 from a baseline "business as usual" (BAU), through national mitigation actions and with international support. This objective is the reduction of emissions baseline scenario.

A study has revealed choose the type of target reduction goals

a. The amount of emissions reduced (in this study eg $\mathrm{x}$ million tonnes of $\mathrm{CO} 2$ equivalent reduced from baseline scenario) or

b. Percent reduction in emissions relative to the baseline scenario of emissions (in this study, for example y $\%$ below baseline emission scenario).

Illustration by reduction of GHG emissions as shown in Figure 2 below. Purpose designed to achieve reductions in GHG emissions being emitted into the atmosphere, in general, for strong environmental/ resistant to climate change. The state of economic growth can be a choice destination based on the intensity of being able to push GDP growth while reducing emissions per unit of output.

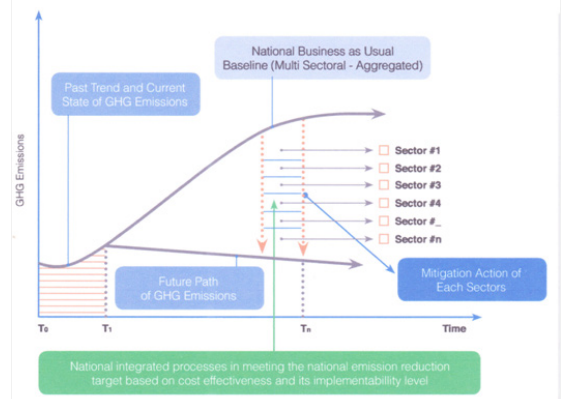

Figure 2 Reductions in emissions of the baseline scenario. ${ }^{8}$

From the perspective of greenhouse gas accounting, goal-related basic scenarios pose a low risk environment since the integrity of the base-case scenario requires the development of technical and political decisions about the various inputs and future events, which may not be accurate. For example, the assumptions chosen for such emissions driver of economic growth and how policies and measures included in the baseline scenario would have a significant impact on emissions in the baseline scenario. Furthermore, the baseline scenario of trying to predict future emissions, which by definition is very difficult and uncertain. Taken together, these problems threaten the accuracy of any baseline scenario and also the integrity of the environment-related purposes baseline scenario.

\section{Choosing a destination level}

Level goal is the amount of emissions or emissions reductions to be undertaken by and is the rate of reduction targets. When selecting the destination level, should take into account several factors, including:

1. Reducing global emissions required to achieve stabilization of atmospheric greenhouse gas emissions consistent limiting warming to $2{ }^{\circ} \mathrm{C}$ above pre-industrial levels, as outlined by climate science

2. History contribution of global emissions.

3. Per capita emissions relative.

4. Key drivers and how emissions are projected to change over time

5. Possible trajectory of emissions based on the basic scenario

6. Results of mitigation assessment, including developing different reduction strategies based on the large reduction opportunities available and examining how emissions projections change with different mitigation strategies

7. Emissions by sector, and incorporate sectoral reduction opportunities to develop the level of purpose

8. A commitment by the government.

\section{Level objectives can be expressed either in terms of}

A single numerical value. A study chose a single numerical value for the level of the destination will choose a single number tons of greenhouse gases, the value per cent, or the intensity of the emission values as the destination level.

The range of numeric values. A study to select a range of numerical values can determine the approximate upper and lower bound level for the purpose, so as to achieve the emission level / intensity in a range that would indicate the achievement of objectives. For example, achieving emission reductions of $5-10 \%$ below baseline. While the numerical value range can offer more flexibility and better accommodate political events and / or unexpected economic, single numeric value provides increased certainty of emission levels at the end of the period goals, assuming the goals are met.

\section{Choosing a destination length:}

1. In accordance with the purpose of long-period goal, which is the period of time in which is committed to fulfill the goal level. Researchers can choose short-term goals, long-term goals, or a combination of both.

2. Short term; Short-term goals are generally considered any purpose with maturities of less than 10 years.

3. Global reductions needed to achieve stabilization of atmospheric greenhouse gas emissions consistent to limit warming to $2{ }^{\circ} \mathrm{C}$ above pre-industrial levels, as outlined by climate science 
4. Mitigation assessment results, including estimated time frame for implementation and scale up mitigation strategies

5. Long destination.

6. In general, the purpose of facilitating a period of long-term planning for major structural changes and capital investments to the greenhouse gas benefits and provide certainty for business and other stakeholders. Moreover, long-term goal can also be used to reduce the risk of unexpected events during a particular year that while an increase in emissions.

7. Short-term goals can mobilize the investment and planning for more rapid emissions reductions and encourage the phaseout of these practices are inefficient and technology.

8. Because the purpose of short-term and long-term offers significant advantages, should adopt and pair of short-term and long-term objectives. This study adopts a short-term goal by 2020 .

\section{Choosing a base year and determining base year emissions}

For the frame of the goal as the reduction of the basic, meaningful and consistent tracking of progress over time requires researchers established a base year and determine the base year emissions.

\section{Base year term and definition}

The base year: the specific historical datum against which emissions are tracked over time

Base period: An average of several years of historical datum against emissions tracked over time

\section{Choosing a base year or base period}

Throughout the standard, the base year is used as shorthand means the base year or base period. Good researchers chose one year or range of years as the base period.

\section{Considerations for choosing the base year or base period}

Data quality: Data of emissions for the base year or base period should be reliable and verification.

Theresearchermustchooseabaseperiodofoneyearorarepresentative, reliable, and verifiable emissions data available and determine the reasons for choosing a particularyear. In a study using the 1990 base year. Underlying assumptions and drivers. All baseline scenarios is based on assumptions about future changes in key drivers of emissions. Therefore, it is important that researchers identify the driver's own emissions for each sector and greenhouse gases covered by the research objectives.

\section{Drivers include}
a. Economic activity
b. Energy supply by fuel type
c. Emission intensity by fuel type
d. Population

Once the driver has been identified, assumptions must be made about how the driver will change from time to time, especially between the base year or base period and the target year.

\section{Results and discussion}

Emissions in a Global Context. Taking into account only the burning of fossil fuels, since 2000 , Indonesia is one of the top $20 \mathrm{CO}_{2}$ emitters, Table 2, many countries in this range has only a slightly higher level or lower emissions from Indonesia, making Indonesia's position is sensitive to changes small. Oak Ridge National Laboratory \& Gregg Marlan, Research Institute for Environment, Energy and Economic Appalachian State University. In the future there is the tendency of the rate of deforestation will be slower due to the declining forest land available. Meanwhile, energy use and fossil fuel emissions will continue to rise in line with GDP growth unless mitigation measures are taken. In the long run, $\mathrm{CO}_{2}$ emissions from the burning of fossil fuels are likely to be far more important are caused by deforestation and changes in land use Fossil fuel GHG emissions per capita in Indonesia is still low compared with other countries. However, as can be seen in Table 3, Indonesia ranks 132 of 216 countries. Emissions per sector of economic activity. See $\mathrm{CO}_{2}$ emissions per sector, Table 4 shows that industrial activity has become a major source of $\mathrm{CO}_{2}$ emissions. One reason is that some sectors have significant $\mathrm{CO}_{2}$ emissions from the transport sector grew steadily but lower than the industrial sector. It is interesting that the emissions from the electricity sector grew most rapidly, since the mid-1990s. $\mathrm{CO}_{2}$ emissions from the household sector grew the slowest, perhaps a reflection of the rising level of household electrification. The household sector is not a major problem in its own sector, but it should be considered how it relates to the overall growth in electricity demand, and how electricity is supplied (for example, the burning of coal for power generation), efforts to increase efficiency, and manage the demand for electricity in the household.

The share of emissions by sector is showing the same thing: the industry is the largest, electricity is fastest growing. While total emissions have grown about 7.9 percent per year (the last two decades), emissions from electricity grew 11 percent / year in the last two decades. Focusing on the share of emissions in the electricity sector, this suggests that the use of coal in power generation is growing much faster than other energy sources. Therefore, in 2004, the proportion of the use of coal for electricity is much higher than other sectors. This is the main reason that the proportion of $\mathrm{CO}_{2}$ from electricity sector grew faster than the proportion of $\mathrm{CO}_{2}$ (coal, oil and gas) and for the consumer category (Industry, Electricity, Transport, and Residential). Industry is currently the largest source of emissions, but further analysis is needed to determine the most subsectors responsible or fastest growing over time. The fastest rising electricity is a major component. This is mainly due to the increase in electricity demand, the plant capacity expansion in recent decades and the effort to improve the combustion of coal to replace oil in power plants burning coal for energy security and price reasons. There has been almost a 5-fold increase in the use of coal since 1994. Transportation is the largest user of fuel, because the growth of the vehicle and the low price of the product liquid fuels for transportation. Low fuel prices (due to subsidies), and improving the efficiency of the vehicle that may occur from time to time. The housing sector is not the main users of coal or gas. Emissions come mainly from burning kerosene by households. In the transport sector, road transport is the largest user 
of fuel oil. Emissions are roughly divided between the use of petrol, gas and diesel. In the residential sector, emissions are almost entirely from kerosene use (mainly for cooking), with zero emissions from the use of LPG. Commercial and public services, especially emissions from the use of natural gas. Agriculture has relatively small emissions from the industrial sector, and mining, as shown in Table 4 and Table 5 below. GHG reduction scenarios by adjusting the government's commitment to reduce Indonesia's greenhouse gas (GHG) emissions in 2020 by $26 \%$, compared to baseline business as usual (BAU) using domestic resources and up to $41 \%$ with international support Has identified 34 sectors as a potential major source of GHG emission reductions: such as agriculture, forestry and land use; energy and transport; industry; and mining. Reductions in GHG emissions using emission estimates of baseline business as usual (BAU) contained in this research. Emissions will come BAU baseline of 799 million $\mathrm{tCO}_{2} \mathrm{e}$ in 2020, which implies an annual growth rate of $9.5 \%$ from the level of 410 million $\mathrm{tCO}_{2} \mathrm{e}$ in 2010. For most sectors, the growth of emissions consistent economic growth, and population growth. Scenario $26 \%$ reduction of GHG emissions requires emission reductions of 203 million $\mathrm{tCO}_{2} \mathrm{e}$ and the reduction of $41 \%$ as much as 328 million $\mathrm{tCO}_{2} \mathrm{e}$ in 2020, details per sector as shown in Table 6 below. ${ }^{11}$

Table 2 Emitter of CO2, the world's top 20, 20109

\begin{tabular}{lll}
\hline Rank & Nation & CO $_{2-}$ Tot (th ton) \\
\hline 1 & China (Mainland) & 2259856 \\
2 & United States of America & 1481608 \\
3 & India & 547811 \\
4 & Russian Federation & $4747 \mid 4$ \\
5 & Japan & 319257 \\
6 & Germany & 203268 \\
7 & Islamic Republic of Iran & 155880 \\
8 & Republic of Korea & 154777 \\
9 & Canada & 136116 \\
10 & United Kingdom & 134580 \\
11 & Saudi Arabia & 126665 \\
12 & South Africa & 125477 \\
13 & Mexico & $12099 \mid$ \\
14 & Indonesia & 118350 \\
15 & Brazil & 114468 \\
16 & Italy (Including San Marino) & 110801 \\
17 & Australia & 101740 \\
18 & France (Including Monaco) & 98520 \\
19 & Poland & 86516 \\
20 & Ukraine & 83121 \\
214 & Lesotho & 5 \\
215 & Saint Helena & 3 \\
216 & Niue & 2 \\
\hline & & \\
\hline
\end{tabular}

Table 3 Emissions of CO2 from fossil fuels per capita, 20109,10

\begin{tabular}{lll}
\hline Rank & Nation & $\mathbf{C O}_{2-}$ Tot (th ton) \\
\hline 1 & Qatar & 10.94 \\
2 & Trinidad And Tobago & 10.3 \\
3 & Kuwait & 9.34 \\
4 & Netherland Antilles & 6.42 \\
5 & Brunei (Darussalam) & 6.26 \\
6 & United Arab Emirates & 6.08 \\
7 & Aruba & 5.89 \\
\hline
\end{tabular}


Table Continued

\begin{tabular}{|c|c|c|}
\hline Rank & Nation & $\mathrm{CO}_{2-}$ Tot (th ton) \\
\hline 8 & Luxembourg & 5.82 \\
\hline 9 & Oman & 5.61 \\
\hline 10 & Bahrain & 5.23 \\
\hline II & $\begin{array}{l}\text { Falkland Islands } \\
\text { (Malvinas) }\end{array}$ & 5.22 \\
\hline 12 & $\begin{array}{l}\text { United States of } \\
\text { America }\end{array}$ & 4.71 \\
\hline 13 & Saudi Arabia & 4.61 \\
\hline 14 & Australia & 4.57 \\
\hline 15 & Gibraltar & 4.27 \\
\hline 16 & New Caledonia & 4.26 \\
\hline 17 & Kazakhstan & 4.23 \\
\hline 18 & Canada & 4 \\
\hline 19 & Faeroe Islands & 3.99 \\
\hline 20 & Estonia & 3.73 \\
\hline 21 & Montserrat & 3.53 \\
\hline 132 & Indonesia & 0.49 \\
\hline 214 & Mali & 0.01 \\
\hline 215 & Burundi & 0.01 \\
\hline 216 & Lesotho & 0 \\
\hline
\end{tabular}

Source:Tom Boden and Bob Andres, Carbon Dioxide Information Analysis Center, Oak Ridge National Laboratory \& Gregg Marland, Research Institute for Environment, Energy and Economics Appalachian State University.

Table 4 Changes in GHG emissions per sector ${ }^{4}$

\begin{tabular}{llll}
\hline GHG emissions by sector & Unit & Available years & $\begin{array}{l}\text { Absolute change from earliest } \\
\text { to latest value }\end{array}$ \\
\hline Energy & MtCO2e & $1990-201 \mathrm{I}$ & $140.46 \%$ \\
Industrial Processes & MtCO2e & $1990-2011$ & $74.48 \%$ \\
Agriculture & MtCO2e & $1990-2011$ & $46.06 \%$ \\
Waste & MtCO2e & $1990-2011$ & $36.43 \%$ \\
Land-Use Change and Forestry & MtCO2 & $1990-2011$ & $90.14 \%$ \\
Bunker Fuels & MtCO2 & $1990-2011$ & $4.17 \%$ \\
GHG emissions - energy sub-sector & & & \\
Electricity/Heat & MtCO2 & $1990-2011$ & $247.42 \%$ \\
Manufacturing/Construction & MtCO2 & $1990-2011$ & $171.29 \%$ \\
Transportation & MtCO2 & $1990-2011$ & $260.06 \%$ \\
Other Fuel Combustion & MtCO2e & $1990-2011$ & $47.56 \%$ \\
Fugitive Emissions & MtCO2e & $1990-2011$ & $4.59 \%$ \\
\hline
\end{tabular}

Table 5 The amount of emissions from energy use per economic sector (\%), average of the period 1995 to 20098

\begin{tabular}{lll}
\hline No. & Sector & Share (\%) \\
\hline & & $4,890,846$ \\
1 & Agriculture, Hunting, Forestry and Fishing & \\
2 & Mining and Quarrying & $8,901,712$ \\
3 & Food, Beverages and Tobacco & 194,185 \\
\hline
\end{tabular}


Table Continued

\begin{tabular}{|c|c|c|}
\hline No. & Sector & Share (\%) \\
\hline 4 & Textiles and Textile Products & 362,249 \\
\hline 5 & Leather, Leather and Footwear & 0,178088 \\
\hline 6 & Wood and Products of Wood and Cork & 0,613607 \\
\hline 7 & Pulp, Paper, Paper , Printing and Publishing & $1,217,019$ \\
\hline 8 & Coke, Refined Petroleum and Nuclear Fuel & $3,105,782$ \\
\hline 9 & Chemicals and Chemical Products & $2,628,913$ \\
\hline 10 & Rubber and Plastics & $0,4 \mid 4898$ \\
\hline II & Other Non-Metallic Mineral & $8,744,488$ \\
\hline 12 & Basic Metals and Fabricated Metal & $4,699,647$ \\
\hline 13 & Machinery, $\mathrm{Nec}$ & 0,141596 \\
\hline 14 & Electrical and Optical Equipment & 0,716525 \\
\hline 15 & Transport Equipment & 0,556733 \\
\hline 16 & Manufacturing, Nec; Recycling & 0,279989 \\
\hline 17 & Electricity, Gas and Water Supply & $2,574,423$ \\
\hline 18 & Construction & $3,048,665$ \\
\hline 19 & $\begin{array}{l}\text { Sale, Maintenance and Repair of Motor } \\
\text { Vehicles and Motorcycles; Retail Sale of Fuel }\end{array}$ & 0,00214 \\
\hline 20 & $\begin{array}{l}\text { Wholesale Trade and Commission Trade, } \\
\text { Except of Motor Vehicles and Motorcycles }\end{array}$ & $\mathrm{I}, 066,5 \mathrm{II}$ \\
\hline 21 & $\begin{array}{l}\text { Retail Trade, Except of Motor Vehicles and } \\
\text { Motorcycles; Repair of Household Goods }\end{array}$ & 0,675031 \\
\hline 22 & Hotels and Restaurants & 0,407432 \\
\hline 23 & Inland Transport & $3,524,759$ \\
\hline 24 & Water Transport & $2,057,593$ \\
\hline 25 & Air Transport & 0,876234 \\
\hline 26 & $\begin{array}{l}\text { Other Supporting and Auxiliary Transport } \\
\text { Activities;Activities of Travel Agencies }\end{array}$ & $0,50 \mid 486$ \\
\hline 27 & Post and Telecommunications & 0,27858 \\
\hline 28 & Financial Intermediation & 0,076377 \\
\hline 29 & Real Estate Activities & 0,108702 \\
\hline 30 & $\begin{array}{l}\text { Renting of M\&Eq and Other Business } \\
\text { Activities }\end{array}$ & 0,150329 \\
\hline 31 & $\begin{array}{l}\text { Public Admin and Defence; Compulsory } \\
\text { Social Security }\end{array}$ & 0,456735 \\
\hline 32 & Education & 0,335406 \\
\hline 33 & Health and Social Work & 0,083896 \\
\hline 34 & $\begin{array}{l}\text { Other Community, Social and Personal } \\
\text { Services }\end{array}$ & 0,368275 \\
\hline 35 & Private Households with Employed Persons & 0 \\
\hline 36 & Extra-territorial organizations and bodies & 0 \\
\hline 37 & Total intermediate consumption & $8,24 I, 656$ \\
\hline
\end{tabular}


Table Continued

\begin{tabular}{lll}
\hline No. & Sector & Share (\%) \\
\hline 38 & Final consumption expenditure by & $1,758,345$ \\
39 & households & 100
\end{tabular}

Table 6 A Scenario GHG emission reductions per sector of the economy for 20208

\begin{tabular}{|c|c|c|c|}
\hline No. & Sector & $\begin{array}{l}26 \% \text { reduction } \\
\left(\mathrm{mt} \mathrm{CO}_{2} \mathrm{e}\right)\end{array}$ & $\begin{array}{l}41 \% \text { reduction }(\mathrm{m} \mathrm{t} \\
\left.\mathrm{CO}_{2} \mathrm{e}\right)\end{array}$ \\
\hline I & Agriculture, Hunting, Forestry and Fishing & $1,016,024$ & $1,602,192$ \\
\hline 2 & Mining and Quarrying & $\mathrm{I}, 849,242$ & $2,916,112$ \\
\hline 3 & Food, Beverages and Tobacco & $4,033,999$ & $6,361,306$ \\
\hline 4 & Textiles and Textile Products & 752,536 & $|| 86,,69 \mid$ \\
\hline 5 & Leather, Leather and Footwear & 0,369961 & 0,5834 \\
\hline 6 & Wood and Products of Wood and Cork & $\mathrm{I}, 274,707$ & $2,010,115$ \\
\hline 7 & Pulp, Paper, Paper , Printing and Publishing & $2,528,235$ & $3,986,833$ \\
\hline 8 & Coke, Refined Petroleum and Nuclear Fuel & $6,451,952$ & $1,017,423$ \\
\hline 9 & Chemicals and Chemical Products & $5,46 \mathrm{I}, 304$ & $8,612,057$ \\
\hline 10 & Rubber and Plastics & 0,861908 & $1,359,163$ \\
\hline II & Other Non-Metallic Mineral & 181,658 & $2,864,607$ \\
\hline 12 & Basic Metals and Fabricated Metal & $9,763,046$ & $\mathrm{I}, 539,557$ \\
\hline 13 & Machinery, Nec & $0,294 I 52$ & 0,463855 \\
\hline 14 & Electrical and Optical Equipment & $|48,85|$ & $2,347,265$ \\
\hline 15 & Transport Equipment & $\mathrm{I}, 156,558$ & $1,823,802$ \\
\hline 16 & Manufacturing, Nec; Recycling & 0,58165 & 0,917217 \\
\hline 17 & Electricity, Gas and Water Supply & $5,348,106$ & $8,433,552$ \\
\hline 18 & Construction & $6,333,297$ & $9,987,122$ \\
\hline 19 & $\begin{array}{l}\text { Sale, Maintenance and Repair of Motor Vehicles and } \\
\text { Motorcycles; Retail Sale of Fuel }\end{array}$ & 0,004445 & 0,00701 \\
\hline 20 & $\begin{array}{l}\text { Wholesale Trade and Commission Trade, Except of } \\
\text { Motor Vehicles and Motorcycles }\end{array}$ & $2,215,569$ & $3,493,782$ \\
\hline 21 & $\begin{array}{l}\text { Retail Trade, Except of Motor Vehicles and } \\
\text { Motorcycles; Repair of Household Goods }\end{array}$ & $1,402,309$ & $2,211,333$ \\
\hline 22 & Hotels and Restaurants & 0,846398 & $\mathrm{I}, 334,705$ \\
\hline 23 & Inland Transport & $7,322,334$ & $\mathrm{I}, 154,676$ \\
\hline 24 & Water Transport & $4,274,444$ & 674,047 \\
\hline 25 & Air Transport & $\mathrm{I}, 820,288$ & $2,870,454$ \\
\hline 26 & $\begin{array}{l}\text { Other Supporting and Auxiliary Transport Activities; } \\
\text { Activities of Travel Agencies }\end{array}$ & $\mathrm{I}, 04 \mathrm{I}, 788$ & $1,642,819$ \\
\hline 27 & Post and Telecommunications & 0,578722 & 0,9126 \\
\hline 28 & Financial Intermediation & 0,158666 & 0,250204 \\
\hline 29 & Real Estate Activities & 0,225818 & 0,356097 \\
\hline 30 & Renting of M\&Eq and Other Business Activities & 0,312293 & 0,492462 \\
\hline 31 & $\begin{array}{l}\text { Public Admin and Defence; Compulsory Social } \\
\text { Security }\end{array}$ & 0,948821 & $1,496,218$ \\
\hline 32 & Education & 0,696772 & $1,098,755$ \\
\hline
\end{tabular}


Table Continued

\begin{tabular}{llll}
\hline No. & Sector & $\begin{array}{l}\mathbf{2 6} \% \text { reduction } \\
\left(\mathbf{m t} \mathbf{C O}_{\mathbf{2}} \mathbf{e}\right)\end{array}$ & $\begin{array}{l}\mathbf{4 1} \% \text { reduction }(\mathbf{m ~ t} \\
\mathbf{C O} \mathbf{~} \mathbf{~})\end{array}$ \\
\hline 33 & Health and Social Work & 0,174285 & 0,274834 \\
34 & Other Community, Social and Personal Services & 0,765055 & $1,206,432$ \\
35 & Private Households with Employed Persons & 0 & 0 \\
36 & Extra-territorial organizations and bodies & 0 & 0 \\
37 & Total intermediate consumption & $1,712,122$ & $2,699,884$ \\
38 & Final consumption expenditure by households & $3,652,785$ & $5,760,161$ \\
39 & Grand Total & 207,74 & 327,59 \\
\hline
\end{tabular}

\section{Conclusion}

Baseline emissions are calculated through decomposition method that takes into account the variables of population growth and development of the Gross Domestic Product and the growth rate of emissions in order to know the rate of change emissions by $9.5 \%$ per year. Has identified 34 economic sectors that have the potential to reduce emissions such as the electricity sector, mining, agriculture, forestry, industry, transport and others. Population and economic growth will increase $\mathrm{CO}_{2}$ emissions. Without intervention to reduce these emissions, Indonesia activity sectors of the economy that uses energy will emit about 799 million tonnes of $\mathrm{CO}_{2}$ in 2020. GHG emission reduction scenarios Indonesia in 2020, with a reduction of $26 \%$ (208 million $\mathrm{tCO}_{2} \mathrm{e}$ ) emissions then be 591 million $\mathrm{tCO}_{2} \mathrm{e}$; and a reduction of $41 \%$ ( 328 million $\mathrm{tCO}_{2}$ e), then emissions would be 471 million $\mathrm{t} \mathrm{CO}_{2}$ e.Further research will be done primarily to strategize GHG emission reductions through mitigation and adaptation programs for each sector of the economy.

\section{Acknowledgements}

None.

\section{Conflict of interest}

The author declares there is no conflict of interest.

\section{References}

1. IPCC. Climate Change 2007: Mitigation of Climate Change. In: Metz B, Davidson OR, Bosch PR, Dave R, Meyer LA, editors. Contribution of Working Group III to the Fourth Assessment Report of the Intergovernmental Panel on Climate Change. Cambridge University
Press, UK and USA: New York; 2007.

2. IPCC. Climate Change 2014: Impacts, Adaptation, and Vulnerability. Working Group II Contribution to the Fifth Assessment Report. Cambridge University Press, Cambridge, UK and New York, NY USA; 2014.

3. IEA. International Energy Agency, Redrawing the Energy-Climate Map. World Energy Outlook Special Report. OECD/IEA, Paris; 2013. 132 p.

4. Boden, Boden TA, G Marland et al. Global, Regional, and National Fossil Fuel $\mathrm{CO}_{2}$ Emissions. Carbon Dioxide Information Analysis Center (CDIAC), Oak Ridge National Laboratory, U.S. Department of Energy, Oak Ridge, Tenn., USA; 2013.

5. EIA. US Energy Information Administration (EIA). International Energy Statistics Washington, DC: U.S. Department of Energy, USA; 2013.

6. WIOD. World Input-Output Database: Construction and Applications, FP7 Research Project, USA; 2009-2012.

7. Kaya Y. Impact of carbon dioxide emission control on GNP Growth: interpretation of proposed scenarios. Scientific Research.2013;4(4).

8. Bappenas. National Development Planning: Indonesia Response to Climate Change. National Agency for Planning and Development. Republic of Indonesia; 2008.

9. Tom Boden, Bob Andres. Carbon Dioxide Information Analysis Center, Oak Ridge National Laboratory, USA.

10. Gregg Marland. Research Institute for Environment, Energy and Economics. Appalachian State University, USA; 2017.

11. WDI: World Development Indicators. World Bank, Washington, D.C, USA; 2009. 